Andrzej R. Pach

\title{
ROZWÓJ SPOŁECZEŃSTWA INFORMACYJNEGO - NADZIEJA CZY ZAGROŻENIE?
}

Źródłem rozważań niech będą dobrze znane słowa Jan Pawła II z początku jego pontyfikatu: „Człowiek dzisiejszy zdaje się być stale zagrożony przez to, co jest jego własnym wytworem, co jest wynikiem pracy jego rąk, a zarazem - i bardziej jeszcze - pracy jego umysłu, dążeń jego woli”' oraz stwierdzenie zawarte w encyklice Laborem exercens, że „obowiązkiem każdego człowieka jest rozwijanie we własnym zakresie nauki i techniki, kultury i moralności, a praca ma właśnie służyć temu rozwojowi”’. Myśli te skłaniają do głębokiej refleksji nad obecnym i przyszłym rozwojem nauki i techniki i jego wpływem na świadomość oraz działania człowieka.

Obecnie mamy do czynienia $\mathrm{z}$ olbrzymim postępem w obszarze nauk biologicznych i medycznych, nauk o materiałach (a w szczególności nanotechnologii), a także $\mathrm{w}$ technologiach informacyjno-komunikacyjnych ICT (information and communications technologies). Technologie te stanowią bazę dla rozwoju społeczeństwa informacyjnego.

Przez pojęcie społeczeństwa informacyjnego rozumie się społeczeństwo, w którym tworzenie, przekazywanie, przetwarzanie i wykorzystywanie informacji ma zasadniczy wpływ na rozwój społeczeństwa w wymiarze gospodarczym, społecznym, politycznym i kulturalnym.

Badanie społeczeństwa informacyjnego w różnych aspektach jest przedmiotem licznych prac prowadzonych w ośrodkach naukowych, niemniej otwartych pozostaje wiele pytań $\mathrm{w}$ zakresie wpływu nowych technologii zarówno na pojedynczego człowieka, jak i na całe społeczeństwa. Z drugiej strony, obserwuje się dynamiczny rozwój oraz pojawianie się nowych technologii ICT, przez co w miarę dokładne określenie kierunków rozwoju społeczeństwa informacyjnego staje

1 Jan Paweł II, enc. Redemptor hominis, 15.

2 Jan Paweł II, enc. Laborem exercens, Wstęp. 
się zadaniem bardzo złożonym, a co za tym idzie, trudno jest odpowiedzieć na pytanie, jakie nadzieje i zagrożenia mogą się w przyszłości pojawić.

Informacja bywa definiowana różnie, zależy to od dyscypliny nauki. Z punktu widzenia społeczeństwa informacyjnego jednak najważniejszą rolę gra ilość informacji, której może dostarczyć wiadomość. Prace amerykańskiego matematyka i inżyniera Claude’a E. Shannona pokazały, że dobrą miarą ilości informacji dostarczanej przez wiadomość jest niepewność co do jej otrzymania albo, inaczej mówiąc, wiadomość jest dla nas tym cenniejsza, im mniej się jej spodziewamy. Przykładowo: informacja, że temperatura w Tatrach w styczniu jest niższa niż 5 stopni Celsjusza, ma dla nas mniejsze znaczenie (bo to jest prawie pewne) niż wiadomość, że w styczniu temperatura w Tatrach jest powyżej 20 stopni Celsjusza (bo to jest mało możliwe). Podstawą rozwoju społeczeństwa informacyjnego jest zatem dostęp i przekazywanie informacji, których wartość jest znacząca zarówno z punktu widzenia jednostki, jak i całego społeczeństwa.

Celem coraz szerszego wprowadzania współczesnych technologii ICT jest zapewnienie dostępu do dowolnej pożądanej informacji jej użytkownikowi, niezależnie od miejsca, w którym się on znajduje i od momentu, w którym chce informację otrzymać. Można stwierdzić, że ten cel został już w znacznej mierze osiągnięty dzięki rozwojowi internetu i bezprzewodowych technologii dostępu do niego.

$\mathrm{W}$ ostatnich latach mamy także do czynienia z procesem, można powiedzieć, „odwrotnym”: każdy z użytkowników otrzymał możliwość umieszczenia dowolnych informacji w sieci, do której może mieć dostęp każdy inny użytkownik internetu na świecie. Przy czym niekoniecznie informacja ta musi być przydatna dla innych użytkowników. W ostatnich latach można też zauważyć, że wymieniać informację między sobą mogą nie tylko ludzie, ale też urządzenia i wtedy mamy do czynienia z tzw. internetem rzeczy (internet of things).

Obecnie coraz więcej usług realizowanych jest za pomocą technologii ICT: usługi bankowe, sprzedaż towarów i usług, załatwianie spraw administracyjnych itp. Przyjrzyjmy się nieco bliżej kilku aplikacjom opartym na technologiach ICT, które są używane dość powszechnie.

Wikipedia (www.en.wikipedia.org). Dostępna bezpłatnie encyklopedia internetowa utrzymywana jest przez organizacje non-profit Wikimedia Foundation. Wikipedia jest redagowana przez ok. 70 tys. osób na całym świecie. Powstała w roku 2001 i początkowo była redagowana tylko w języku angielskim. Obecnie istnieje w 287 wersjach językowych. Ścisłe zasady redagowania poszczególnych haseł są zdefiniowane w zależności od wersji językowej. Wersja angielska zawiera ponad 4,7 mln haseł. Wersja polska zawiera ok. 1,1 mln haseł. Wikipedia ma stanowić jedną powszechną bazę informacji encyklopedycznych, redagowanych na bieżąco przez wolontariuszy i w miarę kolejnych korekt poszczególnych haseł jej dokładność ma stale wzrastać. Ze względu na powszechność dostępu do Wikipedii, mimo 
wielu błędów, jakie obecnie zawiera, stanowi ona główne źródło wiedzy dla olbrzymiej rzeszy ludzi na całym świecie (miesięcznie korzysta z niej ok. 500 mln osób).

Facebook (www.facebook.com) to serwis społecznościowy stworzony w roku 2004 przez piątkę studentów amerykańskich z Uniwersytetu Harvarda. Umożliwia on porozumiewanie się za pomocą komunikatów i treści multimedialnych ludzi na całym świecie. Każda z osób korzystających z Facebooka umieszcza na nim swój profil i określa zakres dostępu do niego. Jak podaje Facebook (www.newsroom.fb.com/company-info), w grudniu 2014 roku na Facebooku było zarejestrowanych blisko 1,2 mld profili. Średnio dziennie korzysta $\mathrm{z}$ niego ok. 890 mln osób, w tym ok. 745 mln osób z urządzeń przenośnych, takich jak smartfony lub tablety. Powszechny dostęp do danych osobowych dostępnych na Facebooku może stwarzać problemy z ochroną prywatności.

Google Maps (www.maps.google.com) to powszechnie dostępny system map cyfrowych wraz z widokami z powietrza, wyglądem ulic i dróg (InStreet), wnętrz pomieszczeń, atrakcyjnych miejsc turystycznych i innych. Umożliwia wirtualne spacery i podróże po świecie. Służy między innymi do planowania podróży, wyszukiwania miejsc, w których są realizowane interesujące nas usługi (restauracja, bankomat, apteka, szpital itp.). Celem strategicznym firmy Google jest stworzenie pełnego widoku całej Ziemi z różną skalą dokładności. Nie we wszystkich krajach filmowanie ulic, a następnie umieszczanie filmów w dostępnych powszechnie bazach danych jest akceptowane. Na przykład w Europie czynnej aplikacji InStreet nie ma Austria. Obawy budzi problem prywatności i zachowania bezpieczeństwa. Chociaż w aplikacji InStreet twarze osób i numery rejestracyjne samochodów są zamazywane, to jednak dane z tej aplikacji mogą być używane np. do szacowania majątku poszczególnych osób na podstawie wyglądu nieruchomości czy zaparkowanych przed nią samochodów.

Rozwój społeczeństwa informacyjnego w chwili obecnej rodzi dwa zasadnicze problemy, które w miarę rozwoju technologii ICT będą występowały z coraz to większą siłą. Są to mianowicie: problem wykorzystywania tzw. big data oraz zachowanie prywatności.

Przez big data, zgodnie z definicją podaną w Wikipedii, rozumiemy „duże, zmienne i różnorodne zbiory danych, których przetwarzanie i analiza jest trudna, ale jednocześnie wartościowa, ponieważ może prowadzić do zdobycia nowej wiedzy"3. Wraz z rozwojem technologii ICT wzrasta niezwykle dynamicznie ilość gromadzonych danych o zachowaniu się użytkowników internetu i innych sieci telekomunikacyjnych. Przykładowo, dane połączeń telefonicznych, frazy wyszukiwane w wyszukiwarkach internetowych itp. są gromadzone w bazach danych firm umożliwiających takie usługi. Dane te pozwalają z jednej strony na podej-

3 Por. https://pl.wikipedia.org/wiki/Big_data (08.09.2015). 
mowanie działań biznesowych, na badania typu socjologicznego lub badania stanu zdrowia społeczeństwa. Z drugiej strony jednak gromadzenie takich danych pozwala również na dokładne scharakteryzowanie osób korzystających z internetu: określenie ich zainteresowań, poglądów, stanu majątkowego itp. Szereg organizacji na świecie zwraca uwagę na to, aby rozwój technologii ICT nie prowadził do utraty prywatności użytkowników tych technologii.

W dalszej części niniejszego artykułu zostanie przedstawiona prognoza rozwoju ICT do roku 2020, a także w kolejnych dekadach. Na tle tej prognozy zostaną zadane pytania odnośnie do wpływu ICT na osobowość człowieka w kontekście obowiązujących norm moralnych.

Do roku 2020:

- Wyświetlacze (ekrany) w różnego rodzaju urządzeniach będą powszechnie wykorzystywały technologie organicznych diod LED (OLED). Charakteryzują się one bardzo wysoką jakością wyświetlanych obrazów, są elastyczne i lekkie. Powszechne też może stać się stosowanie elektronicznego papieru, który pozwoli nam na przyjemniejsze dla oka czytanie tekstów. Rozpowszechni się telewizja o superwysokiej rozdzielczości (4K).

- Drukarki 3D będą na rynku powszechnie dostępne. Drukarki 3D to urządzenia pozwalające na wytwarzanie przedmiotów (obecnie głównie z mas plastycznych) opisanych za pomocą zbioru danych cyfrowych. Można zeskanować w trzech wymiarach jakiś przedmiot, np. rzeźbę, i wynik skanowania zapisać w postaci zbioru cyfrowego, a potem przesłać go w dowolne miejsce na świecie, w którym rzeźba ta zostanie odtworzona przez drukarkę 3D.

- Upowszechnią się tzw. obliczenia w chmurze (cloud computing). Są to usługi pozwalające na uniknięcie dokonywania kosztownych zakupów sprzętu i oprogramowania, a realizacja usług warunkowana jest jedynie dostępem do sieci.

- Internet rzeczy (internet of things) będzie coraz bardziej dostępny. Daje on możliwość bezpośredniej, bez pośrednictwa człowieka, komunikacji pomiędzy dowolnymi urządzeniami mającymi dostęp do sieci. Obecnie np. niektóre liczniki pobieranej energii elektrycznej mają możliwość wysyłania pomiarów wprost do systemu informatycznego. System ten generuje automatycznie faktury i rozsyła je drogą elektroniczną do konsumentów. Gromadzone na bieżąco dane od konsumentów pozwalają m.in. na planowanie rozwoju sieci energetycznych. $Z$ drugiej strony, przesyłanie tego typu pomiarów pozwala na śledzenie konsumentów energii elektrycznej, np. bazując na bieżącym zużyciu energii, łatwo jest stwierdzić, czy ktoś jest w domu lub nie.

- Zostanie przekroczona bariera tryliona $\left(10^{18}\right)$ operacji na sekundę, które będą w stanie wykonywać procesory, stanowiące serce komputerów. Pozwoli to na znaczne zwiększenie ich mocy obliczeniowej. 
- Liczba użytkowników internetu wzrośnie do 5 miliardów (z 1,7 mld w ro$\mathrm{ku} 2010)$.

- Będzie możliwy przekaz tekstu do urządzenia mobilnego za pomocą myśli. Dzięki postępowi w identyfikacji fal mózgowych i dokładności urządzeń, które je mogą identyfikować, będzie na przykład możliwe sterowanie telefonem komórkowym za pomocą myśli. Może to w dużym stopniu pomóc osobom niepełnosprawnym w komunikowaniu się ze światem.

- Moc obliczeniowa przeciętnych komputerów będzie porównywalna ze zdolnościami mózgu w zakresie przetwarzania informacji.

W latach 2021-2030 zapewne:

- W pełni upowszechni się telepraca. Rozwój technologii ICT spowoduje, że praca będzie wykonywana głównie w domu. Niewątpliwie będzie miało to istotny wpływ na zachowania społeczne. $Z$ jednej strony, może sprzyjać życiu rodzinnemu, a z drugiej wpływać na osłabienie więzi z innymi ludźmi.

- Pamięć komputera osobistego osiągnie wielkość 1 petabajta (1 PB), czyli będzie 1 milion razy większa od pamięci obecnych przeciętnych komputerów domowych.

- Powszechna będzie reklama interaktywna oraz gazety interaktywne. Tradycyjne media będą powoli zanikały. Przekaz treści będzie się odbywał poprzez sieć komputerową (internet), a nie tradycyjne radio i telewizję.

- Komputer przejdzie pomyślnie test Turinga: ludzie nie będą w stanie rozpoznać, czy rozmawiają z maszyną, czy z innym człowiekiem.

Być może w latach 2031-2040:

- Programy będą powszechnie wykorzystywały sztuczną inteligencję do pracy dla biznesu i konsumentów, czerpiąc dane ze wszechobecnych urządzeń do komunikacji.

- Pamięć komputera osobistego osiągnie pojemność 1 exabajta (1 EB). Szacuje się, że wszystkie wypowiedziane słowa przez ludzi to ok. 5 EB.

- Zostaną skonstruowane komputery kwantowe, 1000 miliardów szybsze od obecnych komputerów.

- Nastąpi osiągnięcie pełnej wirtualnej rzeczywistości (do pracy i rozrywki).

Niewykluczone, że po roku 2040:

- Będzie możliwe przekazywanie myśli na odległość.

- W wielu pracach roboty zastąpią ludzi.

- Tradycyjny przemysł mediów ulegnie całkowitemu zanikowi. Będzie możliwe kierowanie do człowieka poprzez sieć indywidualnego strumienia danych, dopasowanych do jego indywidualnych zainteresowań, co wyeliminuje potrzebę nadawania masowego.

- Komputer osobisty będzie miał moc przetwarzania danych równą mocy mózgów wszystkich ludzi. 
Rozwój społeczeństwa informacyjnego opartego na nowych technologiach ICT będzie miał fundamentalne znaczenie dla rozwoju kulturowego człowieka i jego zachowań społecznych, a z drugiej strony człowiek będzie w pełni uzależniony od technologii ICT.

Technologie ICT pozwalają na zapisanie całego dziedzictwa kulturowego ludzkości w postaci cyfrowej i umożliwienie każdej osobie nim zainteresowanej dostępu do niego. Obecnie dostęp do najnowszej literatury naukowej odbywa się głównie poprzez sieć, a literatura ta jest dostępna w formie zbiorów elektronicznych, które można sobie ściągnąć do komputera osobistego i ewentualnie wydrukować potrzebny nam artykuł. Interesującą nas literaturę można wyszukać w oparciu o podane przez nas hasła. Inny przykład to polskie Narodowe Archiwum Cyfrowe (www.nac.gov.pl), które m.in. „opracowuje, konserwuje oraz udostępnia archiwalia takie jak zdjęcia, nagrania dźwiękowe oraz filmy, które wchodzą w skład państwowego zasobu archiwalnego". Przedmioty o dużej wartości można zeskanować za pomocą skanerów 3D i je udostępnić badaczom w dowolnym miejscu na świecie. Jest tylko kwestią czasu, kiedy cała twórczość literacka i artystyczna będzie zapisana w postaci cyfrowej.

Możliwość zapisu twórczości literackiej i artystycznej w formie cyfrowej leży u podstaw tzw. powstającej właśnie humanistyki cyfrowej. Humanistykę cyfrową można ogólnie zdefiniować jako naukę zajmującą się tworzeniem metod informatycznych służących do badania twórczości literackiej lub artystycznej, przy czym wynik tych badań byłby trudny do osiągnięcia metodami klasycznymi. Wyobraźmy sobie na przykład, że cała literatura romantyczna została zapisana w postaci cyfrowej, a nas interesuje pytanie, w jakim kontekście w tej literaturze pojawiało się słowo „niebo”. Badacz literatury, który ją bardzo dobrze zna, nie zawsze jest w stanie sobie przypomnieć, w których dziełach i w jakich miejscach się ono pojawiło. I tu przychodzi z pomocą ICT, gdyż poprzez proste zapytanie przesłane do bazy danych możemy otrzymać wszystkie interesujące nas informacje. To prosty przykład, ale można także prowadzić badania nad tym, jak na przestrzeni wieków zmieniało się np. słownictwo stosowane w literaturze angielskiej.

Wraz z rozwojem cywilizacji człowiek w coraz większym stopniu wykorzystywał poznawane zjawiska fizyczne do czynienia życia wygodniejszym i bezpieczniejszym, np. konstruował maszyny czy systemy łączności. Stworzone urządzenia często zastępowały siłę mięśni. Dzięki technologiom ICT mamy obecnie do czynienia z procesem, który wspomaga lub nawet zastępuje pracę mózgu. Prosty przykład: mało kto wykonuje obecnie operacje rachunkowe, korzystając z kartki i ołówka; raczej korzysta w tym celu z kalkulatora, w który jest wyposażone każde urządzenie przenośnie, takie jak telefon komórkowy. Zwalnia to nas z ćwiczenia umiejętności wykonywania przez nasz mózg pewnych abstrakcyjnych operacji, przez co pewne wyuczone sposoby myślenia ulegają destrukcji. Inny przykład 
to wiedza „encyklopedyczna”. Często nauka w szkołach polega na pamięciowym opanowaniu pewnej liczby faktów, które są podstawą do wyciągania wniosków. Technologie ICT pozwalają obecnie na wyszukanie dowolnej informacji, zatem proces zapamiętywania faktów może być ograniczany. Skutkuje to osłabianiem zdolności mózgu do zapamiętywania informacji. Cechą charakterystyczną pracy mózgu są procesy pozwalające na kojarzenie pewnych informacji i wyciąganie $\mathrm{z}$ tego procesu wniosków. Tego typu procesy mogą być odwzorowane za pomocą środków, jakich dostarcza sztuczna inteligencja. Obecnie zdarza się, że na giełdzie zamiast ludzi grają - zgodnie z opracowanymi wcześniej algorytmami - automaty. Mogą one mieć w swojej pamięci znacznie więcej informacji, niż jest w stanie zgromadzić i zapamiętać człowiek, a przy tym są w stanie reagować na zachodzące zjawiska gospodarcze lub polityczne szybciej niż człowiek.

Dochodzimy w tym miejscu do zasadniczego pytania o granicę sztucznego wspomagania procesów myślowych przez technikę i o zagrożenia, które są z tym związane. Niewątpliwie można stwierdzić, że coraz większe uzależnienie cywilizacji od technologii ICT może w przypadku katastrofy, np. bardzo silnego promieniowania elektromagnetycznego, spowodować - gdyby Ziemia znalazła się jego zasięgu - upadek tej cywilizacji. Promieniowanie to może spowodować, że wszystkie urządzenia elektroniczne przestaną działać, zabraknie energii elektrycznej i w konsekwencji wszelkie urządzenia techniczne przestaną funkcjonować. Zakładając, że tego typu katastrofa nie nastąpi, i tak istnieje obawa, iż przejmowanie przez technologie funkcji realizowanych przez mózg pociągnie za sobą jego degenerację, co każe zadać pytanie o istotę człowieka i rolę, jaką Stwórca mu przydzielił.

W obliczu możliwości stwarzanych przez technikę szczególnej mocy nabierają słowa Jana Pawła II z encykliki Redemptor hominis:

Niepokój zaś dotyczy zasadniczej i podstawowej sprawy: czy ów postęp, którego autorem i sprawcą jest człowiek, czyni życie ludzkie na ziemi pod każdym względem „bardziej ludzkim”, bardziej „godnym człowieka... Istotny sens tej „królewskości”, tego „panowania” człowieka w świecie widzialnym, zadanym mu przez samego Stwórcę, leży w pierwszeństwie etyki przed techniką, leży w prymacie osoby w stosunku do rzeczy, leży w pierwszeństwie ducha wobec materii ${ }^{1}$.

1 Jan Paweł II, enc. Redemptor hominis, 15. 


\section{Abstract \\ Information society development - hope or threat?}

The following John Paul II's words from the beginning of his pontificate are a motto of the presentation "The man of today seems ever to be under threat from what he produces, that is to say from the result of the work of his hands and, even more so, of the work of his intellect and the tendencies of his will" (Redemptor Hominis) and the statement from Laborem exercens that "through work man must earn his daily bread and contribute to the continual advance of science and technology and, above all, to elevating unceasingly the cultural and moral level of the society within which he lives in community with those who belong to the same family".

An information society can be meant as a society where the generation, distribution, use, and processing of information has a significant influence on economic, political, and cultural development. Information and communication technologies (ICT) are a basis for such a development.

The issue of ICT and their role in contemporary society have been deeply discussed in the scientific literature, however, many issues are open in terms ICT influence on a human being and whole societies. On the other hand, it can be observed that new technologies dynamically appear, so it seems to be rather difficult to predict potential hopes or threats related to these technologies.

In this article, the key technological trends in communication between human-to-machine and machine-to-machine are outlined. Controversial aspects of acquisition and processing of big data and the digital humanities are described. Issues concerning cybercrimes and privacy protection are mentioned.

A prognosis of ICT development till 2020 and in next three decades is presented. Basing on this prognosis, key questions on the ICT impact on personality in terms of morality are addressed. 